\title{
Limited use of transformative adaptation in response to social-ecological shifts driven by climate change
}

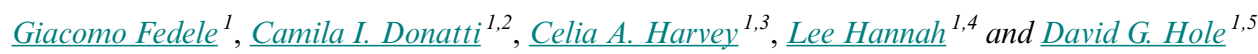

\begin{abstract}
Climate change is increasingly driving fundamental shifts in ecosystems, land use, and human livelihoods. Because of these rapid shifts, some conventional adaptation strategies may have limited success in reducing the impact of climate change. In some circumstances, there will be a need for considering transformative changes as part of adaptation strategies that can provide long-term benefits and address the root causes of vulnerability. However, to date, there is limited understanding of how societies respond to, or drive, transformative changes in social-ecological systems due to climate change impact. We reviewed 60 empirical case studies of shifts in trajectories of social-ecological systems in tropical and subtropical countries that were driven by climate change to identify how societies responded to these shifts and the extent to which societies used transformative adaptation as part of this response. In the case studies, we identified three types of shifts driven by climate change depending on whether the shift occurred in the ecological, social, or social-ecological system. Climate change shifted the trajectories of social-ecological systems by altering the feedback loops connecting soil, water, or vegetation conditions with people's livelihoods and well-being. In response to these shifts, people adjusted land use policies and practices, but only one-quarter of the reported adaptation actions included transformative adaptation. A more holistic understanding of how climate change modifies interactions in social-ecological systems and leads to shifts in system trajectories could help identify appropriate adaptation responses, including transformative adaptation, that provide long-term and sustainable benefits.
\end{abstract}

Key Words: climate change adaptation, ecosystem services, social-ecological systems, sustainable development, transformations

\section{INTRODUCTION}

Climate change is driving unprecedented social and ecological shifts that redefine how people manage land, how nature contributes to human well-being, and how people and nature interact. Since social and ecological systems are coupled (Folke 2006, Berkes et al. 2002), changes in one system can lead to changes in the other and result in new trajectories of entire socialecological systems (Westley et al. 2011, Steffen et al. 2018). Climate change can affect ecological processes that support human well-being and capacity to adapt. For example, reduced precipitation can lead to a lack of forage for livestock production and threatens the livelihoods of pastoralists in Sub-Saharan Africa and elsewhere (Ruf et al. 2015, Rippke et al. 2016). Climate change can also affect people's behaviors and decisions, and those decisions can further exacerbate environmental degradation and people's vulnerabilities. For example, the increased conversion of forests to cropland because of increasing dry conditions can in turn threaten the provision of freshwater (van Noordwijk et al. 2014, Fedele et al. 2017). People can adapt to climate change by using and managing biodiversity and ecosystems, which is referred to as ecosystem-based adaptation (SCBD 2009). However, for nature to continue to provide benefits that help people adapt to climate change, it is important to consider the impacts of climate change on both ecological processes (Lavorel et al. 2015) and social systems (Spangenberg et al. 2014), as well as their interactions (Fedele et al. 2017).

Societies have responded to climate change by using different adaptation strategies that maintain or alter existing socialecological conditions. Coping responses and incremental adaptation to climate change include repairing damaged infrastructure, building higher seawalls, or using more drought- resistant crops, among others. These types of adaptation strategies aim mostly at dealing with changes rather than integrating the expected new social-ecological conditions into possible responses. However, maintaining a system in its current trajectory might fail to provide long-term benefits and address the root causes of vulnerability, especially if such a system is already on an unsustainable trajectory. In addition, coping responses and incremental adaptation may be insufficient in the face of major social and ecological shifts driven by climate change in the long term. Ecosystem-based adaptation strategies that do not plan for future impacts of climate change, especially on ecological processes and biodiversity, may fail to reduce people's vulnerability in the long term (Rickards and Howden 2012, Wise et al. 2014). However, under increasingly changing social and ecological conditions driven by climate change, we might need other adaptation responses that are forward-looking and not only strengthen existing social and ecological capacities to adapt, but also allow desired or unavoidable changes to occur, even if the affected system will be fundamentally transformed (Lavorel et al. 2015, Colloff et al. 2017a). Such approaches include transformative adaptation that refers to strategies aimed at addressing the root causes of vulnerability in the long term by fundamentally changing the structures and functions of ecological or social systems, as well as their feedbacks, to move away from unsustainable trajectories (Feola 2015, Fedele et al. 2019).

Despite the need to manage novel ecological, social, and economic conditions caused by climate change, there is a limited understanding of how societies have attempted to deliberately alter social-ecological system trajectories to reduce their vulnerability to climate change. Lessons from real-world

\footnotetext{
${ }^{1}$ Moore Center for Science, Conservation International, Arlington, VA, USA, ${ }^{2}$ Department of Biological Sciences, Northern Arizona University, Flagsraff, AZ, USA, ${ }^{3}$ Monteverde Institute, Monteverde de Santa Elena, Puntarenas, Costa Rica, ${ }^{4}$ Bren School of Environmental Science \& Management, University of California Santa Barbara, CA, USA, ${ }^{5}$ Department of Biosciences, Durham University, Durham, UK
} 
examples of different societal responses to social-ecological shifts can help inform the policies and programs needed for more intentional and effective adaptation efforts. Literature that analyzes real-world examples of transformation using the conceptual framework of coupled social-ecological systems is limited (but see Rickards and Howden 2012, Moore et al. 2014, Patterson et al. 2017). The few studies available have reported limited implementation of transformative adaptation, for example, in farming practices in Africa (Mapfumo et al. 2017), water management in the United States (Kates et al. 2012), and urban plans in cities around the world (Revi et al. 2014). Part of the reason for the limited implementation of transformative adaptation is that it requires higher human input (e.g., skills, agency, money, time, political will) compared to coping responses or incremental adaptation (Kates et al. 2012, Rickards and Howden 2012, Chung Tiam Fook 2017).

We present a framework for understanding how climate change is driving shifts in a variety of social-ecological systems, review the literature to present real-world examples of responses that have been implemented to adapt to these changes, and identify options for transformative adaptation that could be more effective in reducing people's vulnerability in the long term. Our results can help inform both reactive and unintentional transformations but also the types of capacity and governance building needed in proactive transformative adaptation. We reviewed 60 empirical case studies of shifts in trajectories of social-ecological systems in tropical and subtropical countries that were driven by climate change. We used those case studies to identify when shifts in socialecological systems' trajectories driven by climate change occur, what the drivers and impacts of those shifts were, and how communities responded to those changes, including whether any of those adaptation actions could be considered transformative adaptation. We then discuss how a holistic understanding of the affected systems and their changes - e.g., through causal loop diagrams - can help decision-makers develop more appropriate and effective adaptation responses to climate change impacts. A better understanding of shifts in social-ecological systems' trajectories can help identify when transformative adaptation is needed and how it can be designed to effectively and sustainably reduce climate vulnerability of people and ecosystems.

\section{Conceptual framework for analysis: climate-driven shifts in coupled social-ecological systems}

The concept of transformative adaptation and its application in adaptation projects and policies have received increasing interest from donors, policy-makers, and scientists who are concerned with development and sustainability issues (Feola 2015, Patterson et al. 2017). Recent funds supporting climate change actions explicitly encourage the formulation of adaptation projects and plans that are transformative. For instance, the International Climate Initiative has invested more than $€ 2.8$ billion in climate change adaptation projects that are required to be transformative. Similarly, the Green Climate Fund investment criteria for the committed US\$5 billion include the potential for transformative shifts toward climate-resilient development.

To support this interest in achieving transformative solutions in practice, the literature on transformative adaptation is rapidly growing. Recent conceptual advances have described the distinction between transformative adaptation and other responses to climate change impacts (for reviews, see Pelling et al. 2015, Few et al. 2017, Fazey et al. 2018). As these reviews indicate, there is a general agreement that the concept of transformation refers to complex, nonlinear, and structural changes. However, there is still a conceptual diversity related to transformative adaptation, as indicated in recent studies (O'Brien 2012, Feola 2015, Pelling et al. 2015, Gillard et al. 2016, Patterson et al. 2017). In these studies, the authors argue that the diversity of concepts is influenced by the perception of the outcome of transformative adaptation (prescriptive or descriptive) and the purpose of the study (analytical or solution oriented).

We focus on social and ecological systems that have shifted (or are in the process of shifting) to different states and trajectories because of the impact of climate change, among other drivers of change. These shifts can occur when the social or ecological part of a system crosses a threshold (Collie et al. 2004, Andersen et al. 2009). In the ecological part of systems, examples of new trajectories driven by climate change include the permanent movement of species to new areas, the desertification of dry lands, or the bleaching of corals (Carpenter and Folke 2006), all of which are usually lasting ecological changes. In the social part of systems, examples of new trajectories driven by climate change include the adoption of new livelihood practices (e.g., shifting from cattle production to crop cultivation because of changes in climatic conditions), reforms in governance arrangements or changes in power relations (e.g., from top-down to participatory management of water use quotas), and shifts in collective values or world views, such as the adoption of new low-carbon energy sources (Gelcich et al. 2010, Urbina et al. 2011, Rosen and Olsson 2013).

Climate change can lead to major shifts in entire social-ecological systems in three different ways depending on which part or parts of the system are directly affected (Fig. 1). When climate-related stresses impact the ecological system (E), this in turn can lead to changes in the entire social-ecological system (SES)(E $\rightarrow$ SES) (Fig. 1). An example is the drying of Lake Faguibine in northern Mali due to extended low precipitation, in which the ecological transformation caused communities to change from fishing and farming to harvesting forest products (Djoudi et al. 2013). Similarly, alteration of the social system (S) due to the impact of climate change can drive further changes in the entire socialecological system ( $\mathrm{S} \rightarrow \mathrm{SES}$ ) (Fig. 1). An example is the construction of seawalls and artificial islands to protect people from cyclones and sea level rise in the Maldives, which has damaged the nearby coral reefs and affected eco-tourism activities (Magnan et al. 2016). Finally, a social-ecological shift can be triggered by a climate-related stress that impacts the interactions between the social and the ecological systems (SES $\rightarrow$ SES) (Fig. 1). An example is the case of sea level rise leading to more saltwater intrusion in wetlands that damages and reduces shrimp production in mangrove ecosystems, which are then converted into aquaculture (Herbert et al. 2015).

Social-ecological systems affected by the impact of climate change can respond in several ways. The simplest and usually first response is the use of coping strategies that tend to maintain the affected systems in a similar or business-as-usual state (Perrings 2006, Kates et al. 2012). Another common response is the use of incremental adaptation actions; these are usually more 
Fig. 1. Three ways in which a social-ecological system (SES) can undergo a shift in its trajectory (from state 1 to 2 ) due to climate change and other stress, with examples. Climate change can induce changes in either the ecological (E) or the social (S) subsystem that drive the entire socialecological system across a threshold ( $\mathrm{E} \rightarrow \mathrm{SES}$ and $\mathrm{S} \rightarrow$ SES, respectively). Climate change can also directly impact the interactions between social and ecological systems and push the entire social-ecological system across a threshold (SES $\rightarrow$ SES).
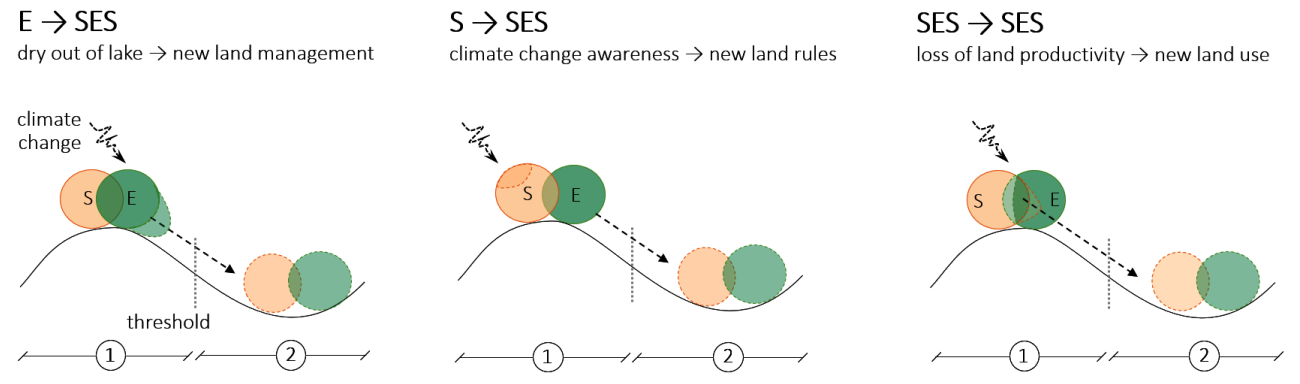

anticipatory actions, which take place before the impacts of climate change are observed, and seek to accommodate changes in the system by building resilience and preserving its original functions (Adger and Jordan 2009, Kates et al. 2012). A final societal response to climate change is the use of transformative adaptation, in which the state of the social-ecological system is permanently altered (Matyas and Pelling 2015, Mapfumo et al. 2017, Fazey et al. 2018). Unlike coping strategies or incremental adaptation, transformative adaptation aims to reduce the root causes of vulnerabilities in the long term (O'Brien 2012, Feola 2015). Transformative adaptation alters a systems' current trajectory toward a new state (Dakos et al. 2015, Hahn and Nykvist 2017), which can be characterized by a different level of sustainability (O'Brien 2012, Olsson et al. 2014) and different power dynamics (Pelling et al. 2015, Blythe et al. 2018). In addition, transformative adaptation can also be part of larger systemic changes, such as governance transitions (e.g., Chaffin et al. 2016), sustainability transformations (e.g., Leach et al. 2012, Stirling 2014), and socio-technical transitions (Biermann et al. 2012, Gorddard et al. 2016). In a gradient of responses from coping to transformative adaptation, the original system's properties and social-ecological interactions are increasingly altered and require increasing human inputs (Fedele et al. 2019).

\section{METHODS}

To improve our understanding of how climate change is driving shifts in trajectories of social-ecological systems, and when transformative adaptation has been used, we reviewed the literature that reported empirical case studies on major changes in social-ecological systems and their responses. We reviewed all empirical case studies about shifts driven by climate change in tropical and subtropical landscapes in developing countries that were found in the regime shifts database (Stockholm Resilience Centre 2017) and in the thresholds database (Resilience Alliance 2017) up to January 2018. We focused the review on these places due to their strong social and ecological interactions, as people highly depend on nature for their livelihoods, which makes such systems particularly prone to changes driven by the impact of, and responses to, climate change. We complemented the studies found in the two databases with other studies about similar shifts that were found in Google Scholar and Web of Science using key words from the studies in the databases (i.e., a combination of "climate change", "transformat* adaptation", "social-ecological system*", and other specific descriptions of the system shifts). In total, we retrieved 60 case studies (15 from the regime shift database, eight from the thresholds database, and 37 from the literature review), which included studies from Africa (31), Latin America (16), and Southeast Asian countries (13).

We reviewed the case studies to identify how climate change in combination with other drivers leads to shifts in social-ecological systems' trajectories, and to identify the impacts of climate change on the system, and the adaptation responses used. After reviewing the information for each of the 60 case studies (see Appendix 1 for individual analysis), we grouped case studies based on the type of shift (e.g., shifts from forests to grassland savannahs due to climate change) (Fig. 1), following the framework, and then selected one example to illustrate each type of shift. For each case example, we developed a causal loop diagram to visualize how social and ecological systems were impacted by climate change. We used causal loops diagrams as a tool to describe systems dynamics under climate change, which is especially relevant for assessing systemic changes and transformative adaptation. The impacts driven by climate change were distinguished according to which part of the system was directly affected (i.e., either the social system, the ecological system, or their interactions). We also documented how social-ecological systems were impacted by other drivers in addition to climate-related ones, such as biophysical, management, social-institutional, or economic changes.

We then analyzed how the impact of climate change caused further shifts in the coupled social-ecological systems. For example, climate change can alter the ecosystem services used for livelihoods (e.g., food provision, water regulation, and ecotourism) or affect the management of natural resources (e.g., water uses, agricultural practices, forest management). For each case study, we noted how people had responded to the shifts, and divided the adopted or suggested response strategies into (i) coping, (ii) incremental adaptation, or (iii) transformative adaptation (see Introduction and classification in Kates et al. 2012, 
Table 1. Summary of shifts in trajectories of social-ecological systems driven by climate change and other drivers, and their impact reported in the 60 case studies (see Appendix 1 for details on the individual case studies).

\begin{tabular}{|c|c|c|c|}
\hline & $\begin{array}{l}\% \text { cases } \\
(n=60)\end{array}$ & Transition & Description \\
\hline \multirow{7}{*}{$\begin{array}{l}\text { Shifts in social- } \\
\text { ecological systems }\end{array}$} & 25 & Cropland transition & From productive to unproductive land \\
\hline & 10 & Fisheries collapse & From fish-rich to fish-poor ocean \\
\hline & 10 & Societal collapse & From settlements to abandoned land \\
\hline & 20 & Forest transition & From old tree-dominated to young tree- or grassland-dominated land \\
\hline & 15 & Bush encroachment & From grassland-dominated to bushland-dominated savannahs \\
\hline & 10 & Aridification & From wetland to dryland \\
\hline & 10 & Coral bleaching & From coral-dominated to macroalgae-dominated reefs \\
\hline \multirow[t]{5}{*}{ Drivers of the shift } & 100 & Climate change & $\begin{array}{l}\text { Increasing temperatures, decreasing precipitation, sea level rise, increasing frequency and } \\
\text { intensity of extreme weather events (e.g., floods, droughts, cyclones) }\end{array}$ \\
\hline & 90 & Environmental degradation & Deforestation, overfishing, excessive use of water, overgrazing, pollution \\
\hline & 30 & $\begin{array}{l}\text { Population growth and } \\
\text { technical development }\end{array}$ & Urbanization, agricultural expansion, tourism, infrastructure, technologies \\
\hline & 10 & $\begin{array}{l}\text { Institutional and policy } \\
\text { reforms }\end{array}$ & Land use policies, land concessions, subsidies, taxes, management plans \\
\hline & 10 & Market fluctuations & Consumer demands, price fluctuations \\
\hline \multirow[t]{5}{*}{ Impact of the shifts } & 60 & Biodiversity & Changes in species abundance and composition \\
\hline & 60 & Provisioning services & Changes in the provision of crops, fish, livestock, or timber \\
\hline & 45 & Regulating services & Changes in water regulation, erosion control, or microclimate regulation \\
\hline & 20 & Cultural services & Changes in tourism activities or cultural practices \\
\hline & 15 & Social well-being & Changes in health and social relations \\
\hline
\end{tabular}

Fedele et al. 2019). In addition, we differentiated the adopted or suggested response strategies according to whether they were based on the use of ecosystems and biodiversity (i.e., ecosystembased adaptation) or not (i.e., based on policies or built infrastructure).

\section{RESULTS}

Case studies of shifts in social-ecological system trajectories driven by climate change and responses

In the 60 reviewed case studies, most shifts in trajectories of social-ecological systems were driven by climate change in combination with at least one other driver of change ( 2.2 drivers \pm 0.8 on average across the 60 studies) (Table 1). The impacts of climate change on social-ecological systems, either directly or indirectly, were driven mostly by higher temperature, lower precipitation, or increased variability and frequency of extreme weather events (e.g., drought and cyclones). Nonclimatic drivers were related to environmental degradation due to the high use of natural resources, such as timber, crops, fish, or livestock (a factor in $90 \%$ of the case studies), followed by increasing population and urbanization (a factor in $30 \%$ of studies), changes in land use policies $(10 \%)$, and fluctuations in market prices $(10 \%)$.

The case studies reported direct impacts of climate change on biodiversity and ecosystem functions as well as on people's livelihoods and well-being. The reported ecological impacts included new species composition and reduced richness (mentioned in $\sim 60 \%$ of the studies). The social impacts, which were mentioned in $15 \%$ of the case studies, included the direct reduction in human well-being; e.g., through increased conflicts over natural resources and vector-borne disease outbreaks. In addition, several studies reported impacts on people's livelihoods due to changes in the provision of ecosystem services. For example, climate change reduced the provision of natural resources such as crops, livestock, fish, and timber (in $60 \%$ of the studies), reduced the regulation of water, climate, and soil processes (45\%), and reduced opportunities for ecotourism $(20 \%)$

Because social and ecological systems are connected by the use and management of land, the impacts of climate change typically affected entire social-ecological systems. Most of the reported shifts in the trajectories of social-ecological systems were cropland transitions (from productive to unproductive cropland in farming communities), forest transitions (from old treedominated to young tree- or grassland-dominated land in forestdependent communities), or bush encroachment (from grasslanddominated to bushland-dominated savannahs in pastoralist communities). Other case studies reported shifts in settlements in coastal areas, shifts in fish stocks and coral reefs in oceans, shifts in algae densities in waterbodies, and aridification of wetlands (see Appendix 1 for the full list of other case studies).

To understand how climate change affected social-ecological systems, we selected one case example to represent each of the three types of shifts (Table 2). The three most frequently reported shifts were (i) shifts from grassland to shrubland in savannahs of Sub-Saharan Africa (E $\rightarrow$ SES), (ii) shifts from settlement to abandoned land on coasts of the Pacific Ocean $(S \rightarrow S E S)$, and (iii) shifts from coffee agroforestry to land without trees in agricultural systems in Latin America (SES $\rightarrow$ SES).

\section{Example 1: Shifts from grassland to shrubland in savannahs of Sub-Saharan Africa $(E \rightarrow$ SES)}

Multiple studies have reported a general increase in trees and shrubs at the expenses of grassland in the savannahs of South Africa, Tanzania, and Kenya (Hudak 1999, Vetter 2009, Oliveras and Malhi 2016; for a full list of references, see Appendix 1). Extended periods of low precipitation reduce soil moisture, especially in the topsoil layers, and favor the growth of bushes 
Table 2. Illustrative examples of case studies for each of the three types (Type I-III) of shifts in social-ecological systems driven by climate change. Climate change and other drivers directly impact part of the system (either ecological [E], social [S], or social-ecological system [SES]), leading to responses that shift the trajectory of the entire social-ecological system.

\begin{tabular}{|c|c|c|c|}
\hline Type of shift & $\begin{array}{l}\text { Type I: } \\
\mathrm{E} \rightarrow \text { SES }\end{array}$ & $\begin{array}{l}\text { Type II: } \\
\mathrm{S} \rightarrow \text { SES }\end{array}$ & $\begin{array}{l}\text { Type III: } \\
\text { SES } \rightarrow \text { SES }\end{array}$ \\
\hline $\begin{array}{l}\text { Illustrative case study } \\
\text { group } \\
\text { Climate change driver }\end{array}$ & $\begin{array}{l}\text { Shifts from grassland to shrubland in } \\
\text { savannahs of Sub-Saharan Africa } \\
\downarrow \text { precipitation, } \\
\uparrow \text { droughts }\end{array}$ & $\begin{array}{l}\text { Shifts from settlement to abandoned land on } \\
\text { coasts of the Pacific Ocean } \\
\uparrow \text { extreme weather events (cyclones, } \\
\text { droughts, El Niño-Southern Oscillation) }\end{array}$ & $\begin{array}{l}\text { Shifts from coffee agroforestry systems to } \\
\text { crop or pasture lands in Latin America } \\
\downarrow \text { precipitation, } \\
\uparrow \text { temperature, } \\
\uparrow \text { plant pest outbreaks }\end{array}$ \\
\hline $\begin{array}{l}\text { Other drivers of } \\
\text { change }\end{array}$ & $\begin{array}{l}\text { Water withdrawal, } \\
\text { fire suppression, } \\
\text { livestock subsidies }\end{array}$ & $\begin{array}{l}\text { Deforestation, } \\
\text { population growth }\end{array}$ & $\begin{array}{l}\text { Population growth, } \\
\text { market prices, } \\
\text { land policies }\end{array}$ \\
\hline $\begin{array}{l}\text { Direct climate change } \\
\text { impact }\end{array}$ & Reduced grassland areas (E) & $\begin{array}{l}\text { Reduced economic activities and well-being } \\
\text { (S) }\end{array}$ & $\begin{array}{l}\text { Reduced coffee productivity and farmer } \\
\text { income (SES) }\end{array}$ \\
\hline Shift in SES trajectory & $\begin{array}{l}\text { Changes in pastoral livelihoods based } \\
\text { on grasslands to other livelihoods }\end{array}$ & $\begin{array}{l}\text { Migration of villagers and abandonment of } \\
\text { settlements and lands }\end{array}$ & $\begin{array}{l}\text { Conversion of coffee agroforestry systems } \\
\text { to other land uses }\end{array}$ \\
\hline Selected references ${ }^{\dagger}$ & $\begin{array}{l}\text { Hudak et al. } 1999 \\
\text { Vetter et al. } 2009 \\
\text { Oliveras and Malhi } 2016\end{array}$ & $\begin{array}{l}\text { Rainbird } 2002 \\
\text { DeMenocal } 2001 \\
\text { Hodell et al. } 1995\end{array}$ & $\begin{array}{l}\text { Fischer and Victor } 2013 \\
\text { Tadesse et al. } 2014 \\
\text { Läderach et al. } 2017\end{array}$ \\
\hline
\end{tabular}

and trees, which can access deeper water compared to grasses. This phenomenon, known as bush encroachment, reduces the income opportunity from savannahs for local communities because dense tree cover limits cattle production and wildlife observation (Abel et al. 2006, Holmes et al. 2012). A reduction in grass, which serves as fuel for fires, together with fire suppression by farmers, reduces the mortality of bushes and trees (e.g., Hudak 1999). Due to the increasing number of trees, evapotranspiration increases, which leads to less soil moisture available for grasses (e.g., Falkenmark and Rockström 2008). This represents a reinforcing feedback loop ( $\mathrm{R} 1$ in Fig. 2) that climate change is exacerbating, which leads to more bushes than grasses in savannahs. Even though natural variations in savannahs are common, the extent of the bushland expansion in Sub-Saharan Africa is unprecedented in the life of many rangeland farmers (Falkenmark and Rockström 2008). In addition, such changes are likely to be persistent, as proven by the number of unsuccessful attempts to revert bushland back to the grassland state (Mata-González et al. 2007).

To maintain livelihood opportunities under climate changedriven bush encroachment in savannahs, landowners have responded with coping or incremental adaptation, such as adjusting their management of vegetation, soil, fire, and livestock (Table 3). Due to the limited grassland available, farmers have reduced the number of livestock, sold livestock, or fenced them (Abel et al. 2006, Vetter 2009). To cope with water scarcity, as bushes compete for water with grasses, the farmers have harvested rainwater, established water use allocations, built water stations, and changed to less water-demanding livestock species (Falkenmark and Rockström 2008, Biggs et al. 2010). To help maintain grassland, farmers have attempted to remove bushes and suppress fires (Hudak 1999). However, most of these strategies have aimed at maintaining grass productivity in the current areas without considering future losses caused by climate change, which increases the risk of maladaptation in the long term.
Fig. 2. A causal loop diagram showing a shift in the trajectory of savannahs from grassland to bushland (bush encroachment) due to lower precipitation driven by climate change. $\mathrm{R}=$ reinforcing feedback loop, in which changes are exacerbated and result in even more changes in the system; $\mathrm{B}=$ balancing feedback loop, in which changes are buffered and result in fewer changes in the system.

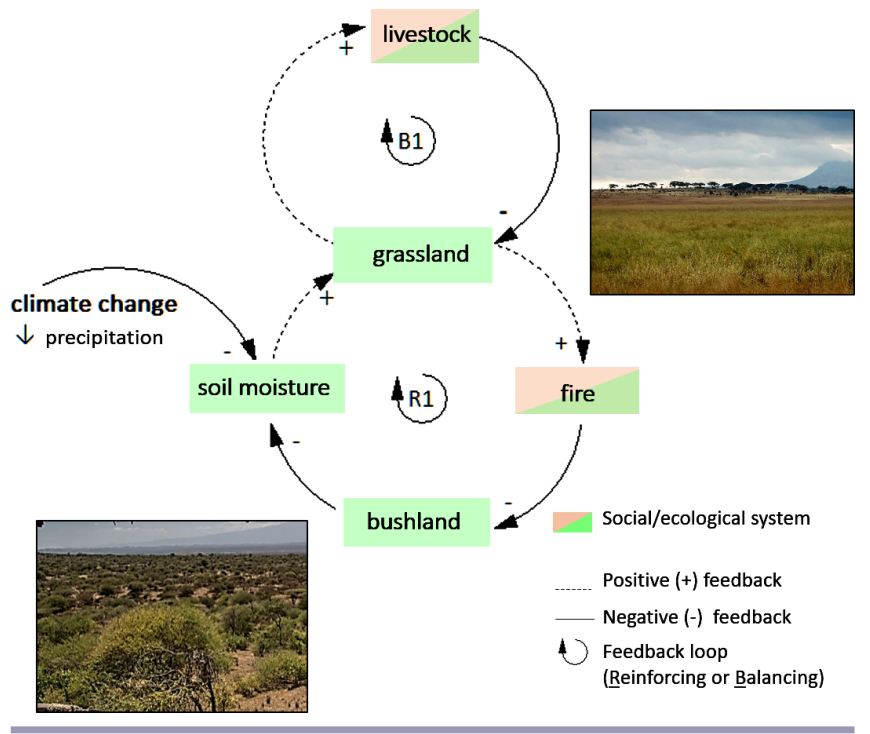

Only a limited number of adaptation responses to bush encroachment (approximately one-quarter) could be considered transformative adaptation that considers future impacts of climate change as well as the root causes of vulnerabilities. One example of transformative adaptation is the attempt to reverse the trend in intensification of grazing in few grasslands in South Africa (Holmes et al. 2012) and the change of nomad pastoralists to sedentary pastoralists in Mali (Djoudi et al. 2013). Mali's local 
Table 3. Overview of implemented and planned adaptation strategies by cattle farmers in response to losses of grassland for pasture because of climate change (bush encroachment). Adaptation strategies are characterized by the type of adaptation measure (coping or incremental, or transformative) and whether they are ecosystem-based adaptation $\left(^{*}\right)$.

\begin{tabular}{|c|c|c|}
\hline System variable & $\begin{array}{l}\text { Examples of coping or incremental adaptation } \\
\text { measures }\end{array}$ & Examples of transformative adaptation measures \\
\hline Livestock & $\begin{array}{l}\text { Reduce or sell livestock } \\
\text { Fence livestock } \\
\text { Water stations for livestock }\end{array}$ & $\begin{array}{l}\text { Grant access to use communal pastureland and incentives for nomad } \\
\text { pastoralists } \\
\text { Diversify livelihoods from farming to ecotourism* or other nonfarming } \\
\text { activities } \\
\text { Eliminate perverse agricultural subsidies (e.g., for large-scale commercial } \\
\text { agriculture and for drought subsidies that encourage overstocking of } \\
\text { livestock) }\end{array}$ \\
\hline $\begin{array}{l}\text { Vegetation } \\
\text { (grassland and } \\
\text { bushland) }\end{array}$ & $\begin{array}{l}\text { Remove bushes } \\
\text { Drought- and heat-tolerant species* }\end{array}$ & $\begin{array}{l}\text { Reform policies for land ownership and management accountability } \\
\text { Introduce compensation for landowners to manage land for conservation }\end{array}$ \\
\hline Soil moisture & $\begin{array}{l}\text { Water use planning and allocations } \\
\text { Water harvesting and conservation measures }\end{array}$ & $\begin{array}{l}\text { Restore large areas of grassland and wetland ecosystems with adapted species } \\
\text { that hinder bush expansion* }\end{array}$ \\
\hline Fire & Fire suppression & Promote regional coordinated controlled fires* \\
\hline
\end{tabular}

authorities have created policies that grant nomad pastoralists the use rights of certain communal grasslands for grazing so that they are not forced to change their nomadic lifestyle and can preserve grasslands with rotational grazing that is considered more resilient to extended dry periods than crop cultivation (Djoudi et al. 2013). In South Africa, authorities have started to eliminate perverse agricultural subsidies that can lead to overgrazing, and to strengthen land rights and management accountability for landowners to encourage conservation practices that help reduce the impact of climate change (Holmes et al. 2012). Additional transformative adaptation strategies that have fundamentally changed land cover and associated uses in South Africa include the restoration of wetland ecosystems (Bohensky 2008), the promotion of large-scale coordinated controlled fires (Hudak 1999), and the diversification or conversion of livelihoods, especially with eco-tourism (Abel et al. 2006), among others. These transformative adaptation strategies are based on changes in the use of ecosystems and on the reform of policies related to land use and access.

\section{Example 2: Shifts from settlement to abandoned land on coasts} of the Pacific Ocean $(S \rightarrow$ SES)

Another social-ecological shift that was common in reviewed case studies was the migration from, and abandonment of, previously inhabited lands driven by the impact of climate change on human activities and needs. Historical archeological records have underscored the contribution of prolonged drought to the collapse of the civilizations of the Maya (Hodell et al. 1995), Easter Island, and other islands in the Pacific (Kirch 1997, Rainbird 2002), and ancient cities on the Pacific coasts of Latin America (Shimada et al. 1991, DeMenocal 2001). Archeological records of the remains of plants, animals, and artifacts in the case studies indicated periods when human activities and environmental conditions significantly changed. Prolonged droughts on small Pacific Islands increased the stress on human and livelihoods security by limiting income opportunities and increasing the dependency of the affected people on the use of scarce natural resources, which exacerbated social tensions. The affected people in the case studies started relying more on the extraction of natural resources; for example, by hunting more wild animals and products for food, cutting trees for timber and energy, and intensifying cultivation of crops and livestock (Kirch 1997, Rainbird 2002). Eventually, because of the amount of severely degraded lands, people put more pressures on the limited remaining resources, which increased the number of people and needs in the remaining hospitable areas. Even though climate change was not the only driver of this societal shift, it increased the stress on human and livelihoods security and led to land use decisions that affected the habitability of certain places.

In these types of case studies, societies affected by drought responded in several ways (Table 4). Societies initially intensified the use of land and natural resources in order to compensate for reduced income. Eventually, they migrated elsewhere when their lands became highly degraded. The archeological records during the times of drought indicated increased levels of deforestation, shifting cultivations, crop and animal production, and hunting and fishing (Kirch 1997, DeMenocal 2001). However, these societal responses were coping and incremental adaptation actions that further exacerbated the environmental degradation caused by droughts and population growth (Fig. 3). Most of these societal responses increased soil erosion and water scarcity, and these in turn further reduced opportunities for agriculture. In addition, the competition for scarce natural resources resulted in conflicts and starvation periods (Rainbird 2002). Less commonly used adaptation strategies included improving irrigation and limiting water use (Shimada et al. 1991, DeMenocal 2001). It is also possible that other coping and incremental adaptation strategies may have been used to respond to those societal shifts, but the archeological records may not be able to reveal them.

In addition to initial coping and incremental adaptation strategies, eventually about one-third of the ancient civilizations seem to have resorted to the use of transformative adaptation measures (Table 4). Entire communities were forced to migrate and abandon their settlements as part of transformative adaptation (Shimada et al. 1991, Kirch 1997, DeMenocal 2001, Núñez et al. 2002). Some civilizations collapsed, such as the Maya and the people living on Easter Island, and the main cities were rebuilt with other social structures in other areas after migration. However, other societies, such as those on Tikopia Island in the 
Table 4. Overview of adaptation strategies implemented by societies whose economic activities and well-being were severely affected by climate change (societal collapse). Adaptation strategies are characterized by the type of adaptation measure (coping or incremental, or transformative) and whether they are ecosystem-based adaptation $\left(^{*}\right)$.

\begin{tabular}{|c|c|c|}
\hline$\underline{\text { System variable }}$ & Examples of coping or incremental adaptation measures & Examples of transformative adaptation measures \\
\hline People and needs & Reduce water use & $\begin{array}{l}\text { Control births and population growth } \\
\text { Migrate to new areas }\end{array}$ \\
\hline Human and & Increase natural resource extraction (e.g., trees, fish, birds)* & Abandon settlements and unproductive lands \\
\hline livelihood security & Introduce new animals (pigs, chickens)* & $\begin{array}{l}\text { Stop some productive activities entirely (e.g., raising livestock, } \\
\text { hunting) }\end{array}$ \\
\hline $\begin{array}{l}\text { Land use } \\
\text { (settlements, } \\
\text { agriculture, } \\
\text { abandoned) }\end{array}$ & $\begin{array}{l}\text { Intensify farming in still-fertile soils } \\
\text { Expand shifting cultivations } \\
\text { Reduce cultivating marginal lands }\end{array}$ & $\begin{array}{l}\text { Reforest degraded lands at a large scale* } \\
\text { Introduce agroforestry practices* }\end{array}$ \\
\hline
\end{tabular}

Pacific, tried to limit human pressure on the environment and started restoring degraded lands (Kirch 1997). The society living on this island regulated population growth by controlling the number of births, started reforestation activities, and banned unsustainable practices such as intensive livestock production (Kirch 1997). These long-term transformative adaptations often involved major changes in behaviors that helped societies shift away from unsustainable development pathways, thereby reducing the risk of societal collapse. Some of these transformative adaptations in social behaviors aimed at reversing the trend of environmental degradation with a more sustainable management of ecosystems, such as forest and agricultural land.

Fig. 3. Causal loop diagram for human migration in coastal areas of the Pacific Ocean driven by the impacts of climate change, among other factors. $\mathrm{R}=$ reinforcing feedback loop, in which changes are exacerbated and result in even more changes in the system.

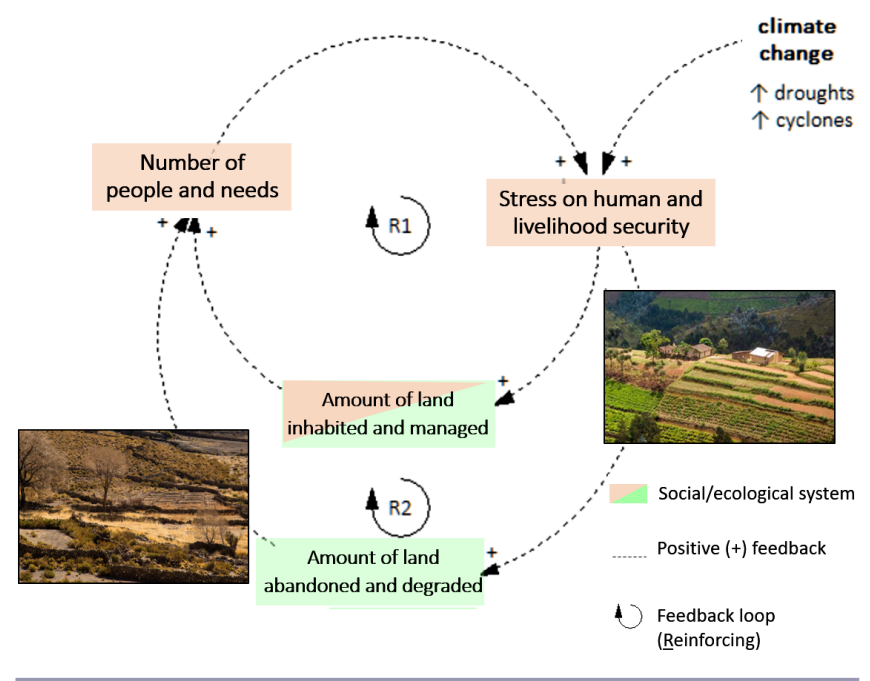

Example 3: Shifts from coffee agroforestry systems to land without trees in Latin America (SES $\rightarrow$ SES)

Twenty-five percent of the studies analyzed reported shifts in agricultural lands toward less productive states because of climate change. One of the crops that is sensitive to climate change is coffee, as identified by case studies in Nicaragua, Guatemala,
Honduras, Costa Rica, Mexico, Ethiopia, and Kenya (e.g., Fischer and Victor 2013, Tadesse et al. 2014, Läderach et al. 2017; for full list of references, see Appendix 1). Higher temperatures, lower rainfall, more pest and disease outbreaks, and changes in pollinators have reduced coffee productivity at low altitudes, especially for Coffea arabica, and these changes in productivity are expected to become more severe as the climate changes further (Eakin et al. 2011, Läderach et al. 2017). In some cases, farmers have adapted their coffee plantations to the new climatic conditions by improving the management of coffee plantations; for example, by incorporating more shade trees and adopting soil conservation practices (Harvey et al. 2017). In other cases, where rising temperatures have already negatively affected coffee production, some farmers have converted less productive treeshaded coffee plantations to other land uses with lower tree diversity, such as pastures or sugar cane, rubber, or oil palm plantations (Fischer and Victor 2013). In the areas where farmers have removed coffee and started using land for crops or livestock, the amount of land with soils suitable for coffee production decreased (i.e., the system shifted from the reinforcing feedback loop R1 to R2) (Fig. 4).

Most of the strategies that farmers are using to maintain coffee production under climate change are coping or incremental adaptation strategies. Farmers have adapted a variety of land management practices and used technical solutions to improve soil suitability and crop productivity (Table 5). Under increasingly drier and hotter conditions, farmers in some areas of Latin America have planted more drought-resistant varieties, increased the density of shade trees, adopted soil conservation practices, increased chemical use, or even introduced irrigation systems (Schroth et al. 2009, Eakin et al. 2011, Läderach et al. 2017). To cope with decreases in coffee productivity, some farmers have also subscribed to crop insurance and introduced weather forecasting systems (Schroth et al. 2009, Läderach et al. 2017). In addition, some coffee farmers have strengthened community organizations and marketing to sell coffee beans at better prices. All these strategies are either coping or incremental adaptation strategies that aim to maintain coffee production under drier and warmer conditions. However, because of the projected severity of climate change, simply trying to maintain coffee production may not be enough in the long term, and transformative adaptation may be needed. 
Table 5. Overview of farmer adaptation strategies to climate change impacts on coffee production. Adaptation strategies are characterized by the type of adaptation measure (coping or incremental, or transformative) and whether they are ecosystem-based adaptation $(*)$.

\begin{tabular}{|c|c|c|}
\hline System variable & Examples of coping or incremental adaptation measures & Examples of transformative adaptation measures \\
\hline $\begin{array}{l}\text { Soil suitability for } \\
\text { coffee }\end{array}$ & $\begin{array}{l}\text { Introduce varieties that are heat-, drought-, pest-, or } \\
\text { disease-tolerant* } \\
\text { Use shade trees, fertilizers, pesticides to maintain } \\
\text { productivity* } \\
\text { Promote use of soil conservation measures* } \\
\text { Establish or improve irrigation systems }\end{array}$ & $\begin{array}{l}\text { Change coffee to other crops or livestock* } \\
\text { Migrate to pursue off-farm employment } \\
\text { Restore large areas of forest ecosystems in upstream watersheds to improve } \\
\text { water flow regulation* }\end{array}$ \\
\hline $\begin{array}{l}\text { Coffee } \\
\text { productivity }\end{array}$ & $\begin{array}{l}\text { Strengthen community organizations and marketing } \\
\text { Apply crop insurance schemes } \\
\text { Introduce weather forecasting systems }\end{array}$ & $\begin{array}{l}\text { Convert coffee production to organic and sustainable value chains that } \\
\text { provide higher income }\end{array}$ \\
\hline $\begin{array}{l}\text { Changes in land } \\
\text { uses (coffee } \\
\text { plantations or } \\
\text { others) }\end{array}$ & $\begin{array}{l}\text { Reduce coffee plantation area or gradually move coffee } \\
\text { plantations uphill }\end{array}$ & $\begin{array}{l}\text { Abandon coffee plantations } \\
\text { Relocate coffee plantation and build infrastructure for coffee production } \\
\text { and trade at higher altitudes } \\
\text { Reforest coffee unproductive and degraded land and introduce financial } \\
\text { schemes (Payment for Ecosystem Services/Reduction of Emissions from } \\
\text { Deforestation and Forest Degradation (REDD+)* }\end{array}$ \\
\hline
\end{tabular}

Fig. 4. Causal loop diagram for shaded coffee plantations that are changed to other land uses without trees due to the impacts of climate change. $\mathrm{R}$ = reinforcing feedback loop, in which changes are exacerbated and result in even more changes in the system; B = balancing feedback loop, in which changes are buffered and result in fewer changes in the system.

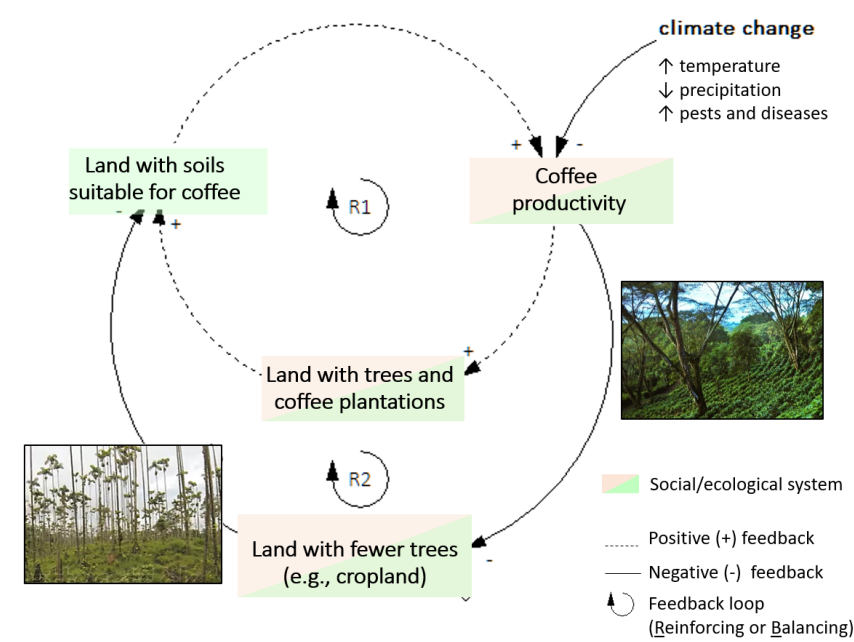

Examples of transformative adaptation actions in coffee production, which represented approximately one-fifth of the adaptation responses, include the relocation of coffee plantations to higher altitudes (with cooler, wetter microclimates), the conversion of coffee plantations to other crops or pasture that are more tolerant of higher temperatures, or even the abandonment of coffee plantations and permanent migration to other areas (Schroth et al. 2009, Moat et al. 2017). However, moving coffee plantations to higher altitudes is not always an option because of land ownership and competing land uses (e.g., protected areas), limited roads and/or processing facilities, or simply the lack of higher elevation land. Additional transformative adaptation options that were mentioned in the cases studies included the reforestation of degraded coffee plantations using Payment for Ecosystem Services schemes, such as water regulation or carbon sequestration (Tadesse et al. 2014, Läderach et al. 2017). In these transformative adaptations based on ecosystems, people used the land in new ways that consider the impact of climate change and the resulting different characteristics of ecosystems.

\section{DISCUSSION}

\section{Climate change as driver of shifts in social-ecological systems' trajectories}

As our review of case studies demonstrates, climate change can drive shifts in social-ecological systems by impacting ecological or social processes individually, as well as by affecting socialecological interactions directly. Because of the interactions between ecological and social processes, climate change can affect the entire social-ecological system, fundamentally modifying it. In the examples we have summarized, changes in one system affected the other coupled system through adjustments in land uses and management. Our review highlights the complexity of understanding climate change impacts on social-ecological systems and demonstrates the importance of using holistic analytical approaches that consider entire social-ecological systems for assessing climate change impacts (Folke 2006, Young et al. 2006, Ostrom 2009). In the examples reviewed, such holistic approaches included both biophysical analysis (e.g., hydrological, climatic, ecological, land cover studies) and social analysis (e.g., behavioral, political, historical, economical, perception studies).

Assessing changes in social-ecological systems driven by climate change through causal loop diagrams can help identify key feedbacks that lead to shifts in the trajectory of the system and allow decision-makers to better understand future conditions. Causal loop diagrams can highlight how changes spread to the entire coupled system as a result of social-ecological interactions, 
such as the use of water, soil, and vegetation for livelihoods. In the reviewed studies, shifts in the trajectories of social-ecological systems occurred when the impact of climate change overwhelmed balancing feedback loops (e.g., grasses in savannahs that are getting drier become scarcer because of overgrazing and increased water competition with trees). Trajectory shifts also happened when new reinforcing feedbacks were introduced as part of people's adaptation to climate change (e.g., rural farmers facing reduced rainfall in Latin America may deforest land to expand crop fields to compensate for reduced agriculture productivity under changing climatic conditions). The diagrams can also highlight potential side effects of adaptation interventions and identify which part of the social-ecological systems will be affected. Therefore, causal loop diagrams can help identify how planned adaptation interventions influence system's behaviors and capacity to adapt to changes. They can also highlight when transformative adaptation may be an appropriate or necessary response to climate change. However, the causal loop diagrams represent only the current situation as reported in the reviewed literature, which is also context dependent; therefore, it remains challenging to predict how systems dynamics will unfold in time and space.

\section{Transformative adaptation using nature as an option to respond to climate change}

People can anticipate or buffer the impact of climate change by deliberately altering the way they interact with nature. In the case examples, people adapted their land uses by introducing new management practices, such as increasing tree cover, restoring grasslands, shifting or abandoning agriculture, or changing watershed management. However, most of the responses to climate change in the case examples we described were coping strategies or incremental adaptation that were intended to maintain the current social-ecological system. These strategies targeted ecological or social processes with immediate use and provided short-term benefits for maintaining crop production, clean water, and useful species. Examples of incremental adaptation strategies included providing drought-resistant species or fertilizers, expanding the area under agriculture, and increasing water harvesting, among others. On the contrary, there were few adaptation responses aimed at improving ecological processes, such as regulation of soil fertility, control of water flows, and maintenance of habitat quality, which are key for system stability and adaptation in the long term (Abel et al. 2016). Responses to climate change might need to go beyond managing ecosystems for increasing productivity to strengthening ecological processes, such as water and soil regulation, that have long-term social and ecological benefits.

Because of the magnitude of the shifts driven by climate change, there are many cases in which transformative adaptation may be necessary to reduce both the ongoing and future vulnerability of people to climate change, and to address the root causes of vulnerability. In the three case examples we explored, societies attempted to cope with or incrementally adapt to climate-driven shifts, but these strategies had only limited success in improving social-ecological conditions and were unable to reverse the decline in land productivity and ecosystem degradation. In these cases, transformative adaptation could have been a more effective strategy to redirect the system toward an improved and new socialecological condition. However, several unknowns remain in this approach because of unintended consequences, power imbalances, and trade-offs (Blythe et al. 2018). As the review of the case examples highlighted, transformative adaptation in social-ecological systems involves the re-evaluation of current interactions between humans and nature, through new management, use, benefit distribution, and values that challenge or redirect the dominant feedback loops (Moore et al. 2014), especially the reinforcing feedback that exacerbates systems' shifts toward less sustainable states (Abel et al. 2016). Examples of transformative adaptation strategies from the case studies reviewed include changes in land uses (e.g., implementation of agroforestry systems, restoration of wetlands) (Bohensky 2008), social institutions (e.g., multi stakeholder water management committees) (Enfors and Gordon 2008), people's values (e.g., farmers's traditions, consumers's behaviors) (Läderach et al. 2017), and awareness of environmental issues (e.g., linkages between populations needs, deforestation, and water provision) (Kirch 1997).

Adaptation strategies based on the use of ecosystems represent opportunities for transformative adaptation because they buffer reinforcing feedback loops that cannot be maintained in the long term and/or restore balancing feedback loops by using sustainable measures with multiple benefits for people and ecosystems (Harvey et al. 2014, Vignola et al. 2015). As shown in the case examples, transformative adaptation can potentially be achieved by restoring natural ecosystems (e.g., grassland, wetlands, or abandoned land), establishing sustainable land management practices (e.g., agroforestry, prescribed fires, selective logging, and replanting), and creating new income sources (e.g., through ecotourism, Payment for Ecosystem Services), to cite a few examples. Ecosystem-based adaptation interventions that are integrated in social-ecological systems and strengthen the capacities of local actors to adapt can help them change or amplify those humanenvironmental relationships that help shift toward a set of desired futures (Bennett et al. 2016, Balvanera et al. 2017). For example, ecosystem-based adaptation measures could include forwardlooking plans to manage ecosystems for benefits that are likely to be provided in the future under climate change. In this way, ecosystem-based adaptation measures could ensure that the benefits people receive from ecosystems are maintained in the future, even if the future ecosystems are different from the current ones (Colloff et al. 2017b). For example, to reduce water scarcity among rural farmers, ecosystem-based adaptation measures could include restoring vegetation in watersheds, as well as providing farmers with skills and tools to change livelihoods, and benefits from the income opportunities resulting from the new conditions.

\section{CONCLUSION}

Our review of 60 case studies on shifts in the trajectories of ecosystems and societies that are driven by climate change in developing countries in the tropics shows several ways in which entire social-ecological systems are impacted by climate change and how people have responded to those shifts by adapting the use and management of land. Most of the reported adaptation responses were coping strategies and incremental adaptation strategies that aimed to maintain the current social-ecological system and rarely addressed the root causes of vulnerabilities and unsustainability in the long term. The use of transformative adaptation, in contrast, was rare. Climate change leads to shifts 
in trajectories of social-ecological systems by directly impacting them or by impacting either the social or ecological system. We showed, through causal loop diagrams, how climate change affects the feedback loops in social-ecological systems that can balance or reinforce the impact of climate change and thus determine whether systems should shift their trajectories. These system dynamics can determine the success of adaptation responses, especially those that aim to be transformative, because decisions made in one place or part of the system can potentially influence long-term adaptation in other places. Considering these altered feedbacks in responses to climate change is important for implementing appropriate and long-term adaptation. As part of the options for reducing vulnerabilities, ecosystem-based adaptation can help reduce key social-ecological feedbacks with unsustainable outcomes, such as people's land use decisions that increase ecosystems' degradation and vulnerability, and redirect them toward more sustainable pathways. Considering transformative adaptation in responses to climate change can help reduce vulnerability, as well as avoid the use of ineffective adaptation strategies. It is particularly important to have a systemic understanding of social-ecological dynamics to evaluate whether transformative adaptation strategies will lead to the desired development outcomes for different actors. Carefully designed transformative adaptation that changes unsustainable development pathways while reducing future vulnerabilities to climate change can provide long-term benefits for both human well-being and ecosystems.

Responses to this article can be read online at: http://www.ecologyandsociety.org/issues/responses. php/11381

\section{Acknowledgments:}

This work was supported by the Ann and Tom Friedman Fellowship for Science at Conservation International, Arlington, VA.

\section{LITERATURE CITED}

Abel, N., D. H. M. Cumming, and J. M. Anderies. 2006. Collapse and reorganization in social-ecological systems: questions, some ideas, and policy implications. Ecology and Society 11(1):17. https://doi.org/10.5751/ES-01593-110117

Abel, N., R. M. Wise, M. J. Colloff, B. H. Walker, J. R. A. Butler, P. Ryan, C. Norman, A. Langston, J. M. Anderies, R. Gorddard, M. Dunlop, and D. O'connell. 2016. Building resilient pathways to transformation when "no one is in charge": insights from Australia's Murray-Darling Basin. Ecology and Society 21(2). https://doi.org/10.5751/ES-08422-210223

Adger, W. N., and A. Jordan. 2009. Sustainability: exploring the processes and outcomes of governance. Pages 3-31 in C. B. Field, editor. Governing sustainability. Cambridge University Press, Cambridge. https://doi.org/10.1017/CBO9780511807756.003

Andersen, T., J. Carstensen, E. Hernández-García, and C. M. Duarte. 2009. Ecological thresholds and regime shifts: approaches to identification. Trends in Ecology \& Evolution 24(1):49-57. https://doi.org/10.1016/j.tree.2008.07.014
Balvanera, P., T. M. Daw, T. A. Gardner, B. Martín-López, A. V. Norström, C. I. Speranza, M. Spierenburg, E. M. Bennett, M. Farfan, M. Hamann, J. N. Kittinger, T. Luthe, M. Maass, G. D. Peterson, and G. Perez-Verdin. 2017. Key features for more successful place-based sustainability research on social-ecological systems: a Programme on Ecosystem Change and Society (PECS) perspective. Ecology and Society 22(1):14. https://doi. org/10.5751/ES-08826-220114

Bennett, E. M., M. Solan, R. Biggs, T. McPhearson, A. V. Norström, P. Olsson, L. Pereira, G. D. Peterson, C. RaudseppHearne, F. Biermann, S. R. Carpenter, E. C. Ellis, T. Hichert, V. Galaz, M. Lahsen, M. Milkoreit, B. Martin López, K. A. Nicholas, R. Preiser, G. Vince, J. M. Vervoort, and J. Xu. 2016. Bright spots: seeds of a good Anthropocene. Frontiers in Ecology and the Environment 14(8):441-448. https://doi.org/10.1002/ fee.1309

Berkes, F., J. Colding, and C. Folke. 2002. Perspectives on resilience. Pages 31-32 in F. Berkes, J. Colding, and C. Folke, editors. Navigating social-ecological systems: building resilience for complexity and change. Cambridge University Press.

Biermann, F., K. Abbott, S. Andresen, K. Bäckstrand, S. Bernstein, M. M. Betsill, H. Bulkeley, B. Cashore, J. Clapp, C. Folke, A. Gupta, J. Gupta, P. M. Haas, A. Jordan, N. Kanie, T. Kluvánková-Oravská, L. Lebel, D. Liverman, J. Meadowcroft, R. B. Mitchell, P. Newell, S. Oberthür, L. Olsson, P. Pattberg, R. Sánchez-Rodríguez, H. Schroeder, A. Underdal, S. C. Vieira, C. Vogel, O. R. Young, A. Brock, and R. Zondervan. 2012. Transforming governance and institutions for global sustainability: key insights from the Earth System Governance Project. Current Opinion in Environmental Sustainability 4 (1):51-60. https://doi.org/10.1016/j.cosust.2012.01.014

Biggs, R., F. R. Westley, and S. R. Carpenter. 2010. Navigating the back loop: fostering social innovation and transformation in ecosystem management. Ecology and Society 15(2):9. https://doi. org/10.5751/ES-03411-150209

Blythe, J., J. Silver, L. Evans, D. Armitage, N. J. Bennett, M. L. Moore, T. H. Morrison, and K. Brown. 2018. The dark side of transformation: latent risks in contemporary sustainability discourse. Antipode 50(5):1206-1223. https://doi.org/10.1111/ anti.12405

Bohensky, E. L. 2008. Discovering resilient pathways for South African water management. Ecology and Society 13(1). https:// doi.org/10.5751/ES-02301-130119

Carpenter, S. R., and C. Folke. 2006. Ecology for transformation. Trends in Ecology \& Evolution 21(6):309-315. https://doi. org/10.1016/j.tree.2006.02.007

Chaffin, B. C., A. S. Garmestani, L. H. Gunderson, M. H. Benson, D. G. Angeler, C. A. Arnold, B. Cosens, R. K. Craig, J. B. Ruhl, and C. R. Allen. 2016. Transformative environmental governance. Annual Review of Environment and Resources 41(1):399-423. https://doi.org/10.1146/annurev-environ-110615-085817

Chung Tiam Fook, T. 2017. Transformational processes for community-focused adaptation and social change: a synthesis. Climate and Development 9(1):5-21. https://doi.org/10.1080/175$\underline{65529.2015 .1086294}$ 
Collie, J. S., K. Richardson, and J. H. Steele. 2004. Regime shifts: Can ecological theory illuminate the mechanisms? Progress in Oceanography 60(2-4):281-302. https://doi.org/10.1016/j. pocean.2004.02.013

Colloff, M. J., S. Lavorel, L. E. van Kerkhoff, C. A. Wyborn, I. Fazey, R. Gorddard, G. M. Mace, W. B. Foden, M. Dunlop, I. C. Prentice, J. Crowley, P. Leadley, and P. Degeorges. $2017 a$. Transforming conservation science and practice for a postnormal world. Conservation Biology 31(5):1008-1017. https://doi. org/10.1111/cobi.12912

Colloff, M. J., B. Martín-López, S. Lavorel, B. Locatelli, R. Gorddard, P. Y. Longaretti, G. Walters, L. van Kerkhoff, C. Wyborn, A. Coreau, R. M. Wise, M. Dunlop, P. Degeorges, H. Grantham, I. C. Overton, R. D. Williams, M. D. Doherty, T. Capon, T. Sanderson, and H. T. Murphy. 2017b. An integrative research framework for enabling transformative adaptation. Environmental Science \& Policy 68:87-96. https://doi.org/10.1016/ j.envsci.2016.11.007

Dakos, V., S. R. Carpenter, E. H. van Nes, and M. Scheffer. 2015. Resilience indicators: prospects and limitations for early warnings of regime shifts. Philosophical Transactions of the Royal Society B: Biological Sciences 370(1659):1-10. https://doi.org/10.1098/ $\underline{\text { rstb. } 2013.0263}$

DeMenocal, P. B. 2001. Cultural responses to climate change during the late Holocene. Science 292(5517):667-673.

Djoudi, H., M. Brockhaus, and B. Locatelli. 2013. Once there was a lake: vulnerability to environmental changes in northern Mali. Regional Environmental Change 13(3):493-508. https://doi. org/10.1007/s10113-011-0262-5

Eakin, H., L. A. Bojórquez-Tapia, R. M. Diaz, E. Castellanos, and J. Haggar. 2011. Adaptive capacity and social-environmental change: theoretical and operational modeling of smallholder coffee systems response in Mesoamerican Pacific Rim. Environmental Management 47(3):352-367. https://doi.org/10.1007/ s00267-010-9603-2

Enfors, E. I., and L. J. Gordon. 2008. Dealing with drought: the challenge of using water system technologies to break dryland poverty traps. Global Environmental Change 18(4):607-616. https://doi.org/10.1016/j.gloenvcha.2008.07.006

Falkenmark, M., and J. Rockström. 2008. Building resilience to drought in desertification-prone savannas in Sub-Saharan Africa: the water perspective. Natural Resources Forum 32(2):93-102. https://doi.org/10.1111/j.1477-8947.2008.00177.x

Fazey, I., P. Moug, S. Allen, K. Beckmann, D. Blackwood, M. Bonaventura, K. Burnett, M. Danson, R. Falconer, A. S. Gagnon, R. Harkness, A. Hodgson, L. Holm, K. N. Irvine, R. Low, C. Lyon, A. Moss, C. Moran, L. Naylor, K. O'Brien, S. Russell, S. Skerratt, J. Rao-Williams, and R. Wolstenholme. 2018. Transformation in a changing climate: a research agenda. Climate and Development 10(3):197-217. https://doi.org/10.1080/175655$\underline{29.2017 .1301864}$

Fedele, G., C. I. Donatti, C. A. Harvey, L. Hannah, and D. G. Hole. 2019. Transformative adaptation to climate change for sustainable social-ecological systems. Environmental Science \& Policy 101:116-125. https://doi.org/10.1016/j.envsci.2019.07.001
Fedele, G., B. Locatelli, and H. Djoudi. 2017. Mechanisms mediating the contribution of ecosystem services to human wellbeing and resilience. Ecosystem Services 28:43-54. https://doi. org/10.1016/j.ecoser.2017.09.011

Feola, G. 2015. Societal transformation in response to global environmental change: a review of emerging concepts. Ambio 44 (5):376-390. https://doi.org/10.1007/s13280-014-0582-Z

Few, R., D. Morchain, D. Spear, A. Mensah, and R. Bendapudi. 2017. Transformation, adaptation and development: relating concepts to practice. Palgrave Communications 3:17092. https:// doi.org/10.1057/palcomms.2017.92

Fischer, E., and B. Victor. 2013. High-end coffee and smallholding growers in Guatemala. Latin American Research Review 49 (1):155-177. https://doi.org/10.1353/lar.2014.0001

Folke, C. 2006. Resilience: the emergence of a perspective for social-ecological systems analyses. Global Environmental Change 16(3):253-267. https://doi.org/10.1016/j.gloenvcha.2006.04.002

Gelcich, S., T. P. Hughes, P. Olsson, C. Folke, O. Defeo, M. Fernandez, S. Foale, L. H. Gunderson, C. Rodriguez-Sickert, M. Scheffer, R. S. Steneck, and J. C. Castilla. 2010. Navigating transformations in governance of Chilean marine coastal resources. Proceedings of the National Academy of Sciencesof the United States of America 107(39):16794-16799. https://doi. org/10.1073/pnas.1012021107

Gillard, R., A. Gouldson, J. Paavola, and J. van Alstine. 2016. Transformational responses to climate change: beyond a systems perspective of social change in mitigation and adaptation. Wiley Interdisciplinary Reviews: Climate Change 7(2):251-265. https:// doi.org/10.1002/wcc.384

Gorddard, R., M. J. Colloff, R. M. Wise, D. Ware, and M. Dunlop. 2016. Values, rules and knowledge: adaptation as change in the decision context. Environmental Science \& Policy 57:60-69. https://doi.org/10.1016/j.envsci.2015.12.004

Hahn, T., and B. Nykvist. 2017. Are adaptations self-organized, autonomous, and harmonious? Assessing the social-ecological resilience literature. Ecology and Society 22(1). https://doi. org/10.5751/ES-09026-220112

Harvey, C. A., M. Chacón, C. I. Donatti, E. Garen, L. Hannah, A. Andrade, L. Bede, D. Brown, A. Calle, J. Chará, C. Clement, E. Gray, M. H. Hoang, P. Minang, A. M. Rodríguez, C. SeebergElverfeldt, B. Semroc, S. Shames, S. Smukler, E. Somarriba, E. Torquebiau, J. van Etten, and E. Wollenberg. 2014. Climate-smart landscapes: opportunities and challenges for integrating adaptation and mitigation in tropical agriculture. Conservation Letters 7(2):77-90. https://doi.org/10.1111/conl.12066

Harvey, C. A., M. R. Martínez-Rodríguez, J. M. Cárdenas', J. Avelino, B. Rapidel, R. Vignola, C. I. Donatti, and S. VilchezMendoza. 2017. The use of ecosystem-based adaptation practices by smallholder farmers in Central America. Agriculture, Ecosystems \& Environment 246:279-290. https://doi.org/10.1016/ j.agee.2017.04.018

Herbert, E. R., P. Boon, A. J. Burgin, S. C. Neubauer, R. B. Franklin, M. Ardon, K. N. Hopfensperger, L. P. M. Lamers, P. Gell, and J. A. Langley. 2015. A global perspective on wetland 
salinization: ecological consequences of a growing threat to freshwater wetlands. Ecosphere 6:1-43. https://doi.org/10.1890/ ES14-00534.1

Hodell, D. A., J. H. Curtis, and M. Brenner. 1995. Possible role of climate in the collapse of Classic Maya civilization. Nature 375 (6530):391-394. https://doi.org/10.1038/375391a0

Holmes, P. M., A. G. Rebelo, C. Dorse, and J. Wood. 2012. Can Cape Town's unique biodiversity be saved? Balancing conservation imperatives and development needs. Ecology and Society 17(2):28. https://doi.org/10.5751/ES-04552-170228

Hudak, A. T. 1999. Rangeland mismanagement in South Africa: failure to apply ecological knowledge. Human Ecology 27 (1):55-78. https://doi.org/10.1023/A:1018705300730

Kates, R. W., W. R. Travis, and T. J. Wilbanks. 2012. Transformational adaptation when incremental adaptations to climate change are insufficient. Proceedings of the National Academy of Sciences of the United States of America 109 (19):7156-7161. https://doi.org/10.1073/pnas.1115521109

Kirch, P. V. 1997. Microcosmic histories: island perspectives on "global" change. American Anthropologist 99(1):30-42. https:// doi.org/10.1525/aa.1997.99.1.30

Läderach, P., J. Ramirez-Villegas, C. Navarro-Racines, C. Zelaya, A. Martinez-Valle, and A. Jarvis. 2017. Climate change adaptation of coffee production in space and time. Climatic Change 141(1):47-62. https://doi.org/10.1007/s10584-016-1788-9

Lavorel, S., M. J. Colloff, S. McIntyre, M. D. Doherty, H. T. Murphy, D. J. Metcalfe, M. Dunlop, R. J. Williams, R. M. Wise, and K. J. Williams. 2015. Ecological mechanisms underpinning climate adaptation services. Global Change Biology 21(1):12-31. https://doi.org/10.1111/gcb.12689

Leach, M., J. Rockström, P. Raskin, I. Scoones, A. C. Stirling, A. Smith, J. Thompson, E. Millstone, A. Ely, E. Arond, C. Folke, and P. Olsson. 2012. Transforming innovation for sustainability. Ecology and Society 17(2):11. https://doi.org/10.5751/ES-04933-170211

Magnan, A. K., E. L. F. Schipper, M. Burkett, S. Bharwani, I. Burton, S. Eriksen, F. Gemenne, J. Schaar, and G. Ziervogel. 2016. Addressing the risk of maladaptation to climate change. Wiley Interdisciplinary Reviews: Climate Change 7(5):646-665. https:// doi.org/10.1002/wcc.409

Mapfumo, P., M. Onyango, S. K. Honkponou, E. H. El Mzouri, A. Githeko, L. Rabeharisoa, J. Obando, N. Omolo, A. Majule, F. Denton, J. Ayers, and A. Agrawal. 2017. Pathways to transformational change in the face of climate impacts: an analytical framework. Climate and Development 9(5):439-451. https://doi.org/10.1080/17565529.2015.1040365

Mata-González, R., B. Figueroa-Sandoval, F. Clemente, and M. Manzano. 2007. Vegetation changes after livestock grazing exclusion and shrub control in the southern Chihuahuan Desert. Western North American Naturalist 67(1):63-70. https://doi. org/10.3398/1527-0904(2007)67[63:VCALGE]2.0.CO;2

Matyas, D., and M. Pelling. 2015. Positioning resilience for 2015: the role of resistance, incremental adjustment and transformation in disaster risk management policy. Disasters 39(s1):s1-s18. https://doi.org/10.1111/disa.12107
Moat, J., J. Williams, S. Baena, T. Wilkinson, S. Demissew, C. Z. K., T. W. Gole, and Davis. 2017. Coffee farming and climate change in Ethiopia: impacts, forecasts, resilience and opportunities - summary. Strategic Climate Institutions Programme. Royal Botanic Gardens, Kew, UK.

Moore, M. L., O. Tjornbo, E. Enfors, C. Knapp, J. Hodbod, J. A. Baggio, A. Norström, P. Olsson, and D. Biggs. 2014. Studying the complexity of change: toward an analytical framework for understanding deliberate social-ecological transformations. Ecology and Society 19(4):54. https://doi.org/10.5751/ES-06966-190454

Núñez, L., M. Grosjean, and I. Cartajena. 2002. Human occupations and climate change in the Puna de Atacama, Chile. Science 298(5594):821-824. https://doi.org/10.1126/science.1076449

O'Brien, K. 2012. Global environmental change II: from adaptation to deliberate transformation. Progress in Human Geography 36(5):667-676. https://doi.org/10.1177/0309132511425767

Oliveras, I., and Y. Malhi. 2016. Many shades of green: the dynamic tropical forest-savannah transition zones. Philosophical Transactions of the Royal Society B: Biological Sciences 371 (1703). https://doi.org/10.1098/rstb.2015.0308

Olsson, P., V. Galaz, and W. J. Boonstra. 2014. Sustainability transformations: a resilience perspective. Ecology and Society 19 (4):1. https://doi.org/10.5751/ES-06799-190401

Ostrom, E. 2009. A general framework for analyzing sustainability of social-ecological systems. Science 325 (5939):419-422. https://doi.org/10.1126/science.1172133

Patterson, J., K. Schulz, J. Vervoort, S. van der Hel, O. Widerberg, C. Adler, M. Hurlbert, K. Anderton, M. Sethi, and A. Barau. 2017. Exploring the governance and politics of transformations towards sustainability. Environmental Innovation and Societal Transitions 24:1-16. https://doi.org/10.1016/j.eist.2016.09.001

Pelling, M., K. O’Brien, and D. Matyas. 2015. Adaptation and transformation. Climatic Change 133(1):113-127. https://doi. org/10.1007/s10584-014-1303-0

Perrings, C. 2006. Resilience and sustainable development. Environment and Development Economics 11(4):417-427. https:// doi.org/10.1017/S1355770X06003020

Rainbird, P. 2002. A message for our future? The Rapa Nui (Easter Island) ecodisaster and Pacific island environments. World Archaeology 33(3):436-451. https://doi.org/10.1080/00438240120107468

Revi, A., D. E. Satterthwaite, F. Aragón-Durand, J. CorfeeMorlot, R. Kiunsi, M. Pelling, D. Roberts, and W. Solecki. 2014. Urban areas. Climate Change 2014 Impacts, Adaptation, and Vulnerability:535-612.

Rickards, L., and S. M. Howden. 2012. Transformational adaptation: agriculture and climate change. Crop \& Pasture Science 63:240-250. https://doi.org/10.1071/CP11172

Rippke, U., J. Ramirez-Villegas, A. Jarvis, S. J. Vermeulen, L. Parker, F. Mer, B. Diekkrüger, A. J. Challinor, and M. Howden. 2016. Timescales of transformational climate change adaptation in Sub-Saharan African agriculture. Nature Climate Change 6 (6):605-609. https://doi.org/10.1038/nclimate2947 
Rosen, F., and P. Olsson. 2013. Institutional entrepreneurs, global networks, and the emergence of international institutions for ecosystem-based management: the Coral Triangle Initiative. Marine Policy 38:195-204. https://doi.org/10.1016/j.marpol.2012.05.036

Ruf, F., G. Schroth, and K. Doffangui. 2015. Climate change, cocoa migrations and deforestation in West Africa: What does the past tell us about the future? Sustainability Science 10 (1):101-111. https://doi.org/10.1007/s11625-014-0282-4

Schroth, G., P. Laderach, J. Dempewolf, S. Philpott, J. Haggar, H. Eakin, T. Castillejos, J. G. Moreno, L. S. Pinto, R. Hernandez, A. Eitzinger, and J. Ramirez-Villegas. 2009. Towards a climate change adaptation strategy for coffee communities and ecosystems in the Sierra Madre de Chiapas, Mexico. Mitigation and Adaptation Strategies for Global Change 14(7):605-625. https://doi.org/10.1007/s11027-009-9186-5

Secretariat of the Convention on Biological Diversity (SCBD). 2009. Connecting biodiversity and climate change mitigation and adaptation: report of the second ad hoc technical expert group on biodiversity and climate change. Technical Series No. 41. Montreal, Que.

Shimada, I., C. B. Schaaf, L. G. Thompson, and E. MosleyThompson. 1991. Cultural impacts of severe droughts in the prehistoric Andes: application of a 1,500-year ice core precipitation record. World Archaeology 22(3):247-270. https:// doi.org/10.1080/00438243.1991.9980145

Spangenberg, J. H., C. Görg, D. T. Truong, V. Tekken, J. V. Bustamante, and J. Settele. 2014. Provision of ecosystem services is determined by human agency, not ecosystem functions. Four case studies. International Journal of Biodiversity Science, Ecosystem Services and Management 10(1):40-53.

Steffen, W., J. Rockström, K. Richardson, T. M. Lenton, C. Folke, D. Liverman, C. P. Summerhayes, A. D. Barnosky, S. E. Cornell, M. Crucifix, J. F. Donges, I. Fetzer, S. J. Lade, M. Scheffer, R. Winkelmann, and H. J. Schellnhuber. 2018. Trajectories of the Earth System in the Anthropocene. Proceedings of the National Academy of Sciences of the United States of America 115 (33):8252-8259. https://doi.org/10.1073/pnas.1810141115

Stirling, A. 2014. Transforming power: social science and the politics of energy choices. Energy Research \& Social Science 1:83-95. https://doi.org/10.1016/j.erss.2014.02.001

Tadesse, G., E. Zavaleta, and C. Shennan. 2014. Effects of landuse changes on woody species distribution and above-ground carbon storage of forest-coffee systems. Agriculture, Ecosystems \& Environment 197:21-30. https://doi.org/10.1016/j.agee.2014.07.008

Urbina, M. A., M. E. Forster, and C. N. Glover. 2011. Leap of faith: voluntary emersion behaviour and physiological adaptations to aerial exposure in a non-aestivating freshwater fish in response to aquatic hypoxia. Physiology \& Behavior 103 (2):240-247. https://doi.org/10.1016/j.physbeh.2011.02.009

van Noordwijk, M., V. Bizard, P. Wangpakapattanawong, H. L. Tata, G. B. Villamor, and B. Leimona. 2014. Tree cover transitions and food security in Southeast Asia. Global Food Security 3 (3-4):200-208. https://doi.org/10.1016/j.gfs.2014.10.005
Vetter, S. 2009. Drought, change and resilience in South Africa's arid and semi-arid rangelands. South African Journal of Science 105(1-2):29-33.

Vignola, R., C. A. Harvey, P. Bautista-Solis, J. Avelino, B. Rapidel, C. Donatti, and R. Martinez. 2015. Ecosystem-based adaptation for smallholder farmers: definitions, opportunities and constraints. Agriculture, Ecosystems \& Environment 211:126-132. https://doi.org/10.1016/j.agee.2015.05.013

Westley, F., P. Olsson, C. Folke, T. Homer-Dixon, H. Vredenburg, D. Loorbach, J. Thompson, M. Nilsson, E. Lambin, J. Sendzimir, B. Banerjee, V. Galaz, and S. van der Leeuw. 2011. Tipping toward sustainability: emerging pathways of transformation. Ambio 40 (7):762-780. https://doi.org/10.1007/s13280-011-0186-9

Wise, R. M., I. Fazey, M. Stafford Smith, S. E. Park, H. C. Eakin, E. R. M. Archer van Garderen, and B. Campbell. 2014. Reconceptualising adaptation to climate change as part of pathways of change and response. Global Environmental Change 28:325-336. https://doi.org/10.1016/j.gloenvcha.2013.12.002

Young, O. R., F. Berkhout, G. C. Gallopin, M. A. Janssen, E. Ostrom, and S. van der Leeuw. 2006. The globalization of socioecological systems: an agenda for scientific research. Global Environmental Change 16(3):304-316. https://doi.org/10.1016/j. gloenvcha.2006.03.004 
Appendix 1. Database with the extracted information from the 60 case studies reviewed.

Please click here to download file 'appendix1.xlsx'. 